\title{
Organic and mineral fertilizer effects on the yield and mineral contents of carrot (Daucus carota)
}

\author{
Kovács, A. B., Kremper, R., Jakab, A. \& Szabó, A. \\ University of Debrecen, Centre for Agricultural and Applied Economic Sciences, Institute of Agricultural \\ Chemistry and Soil Science, H-4032 Debrecen, Böszörményi 138, Hungary \\ E-mail: kovacsa@agr.unideb.hu
}

\begin{abstract}
Summary: A greenhouse pot experiment was conducted to investigate the effects of ammonium-nitrate, food waste compost, bacterial fertilizer (EM-1) and their combinations on production and nutrient contents of carrot. The study was conducted on a calcareous chernozem and acidic sandy soils in a randomized complete block design with 8 treatments and four replications. $\mathrm{NH}_{4} \mathrm{NO}_{3}$ in chernozem soil increased the weight of carrot leaves only, while in sandy soil resulted in reduced yield and highly increased $\mathrm{NO}_{3}-\mathrm{N}_{\text {content }}$ of roots. Sandy soil showed higher response of biomass production to food waste compost application than chernozem soil. The highest carotenoid content of roots was measured with compost treatment. Combined application of compost and $\mathrm{NH}_{4} \mathrm{NO}_{3}$ in chernozem proved to be good combination but in sandy soil have turn out to be less favourable than sole compost treatment. Bacterial fertilizer (EM-1) did not cause marked effect on the yield parameters, but caused increased phosphorus content of plant. In chernozem soil the maximum yield parameters were achieved with the combined treatment of ammonium-nitrate+compost+EM-1. In sandy soil the most favourable treatment proved to be the compost treatment. Results suggest that application of food waste compost as a nutrient source could be a promising agrochemical practice especially in soils having low organic material and low nutrient supply.
\end{abstract}

Key words: mineral fertilizer, food waste compost, bacterial fertilizer, nutrient, carrot

\section{Introduction}

The conventional agriculture uses large quantities of synthetic fertilizers and pesticides to control diseases and to provide nutrients to crops. These practices may have led to a decrease in organic matter content and hence to a decline in soil quality. Organic fertilization is one of the oldest methods of soil cultivation. Every possible type of organic manuring has got vital importance for soil fertility preservation (Petróczki, 2004). Organic fertilizers are major components of organic farming, which offer an economically attractive and ecologically sound means of reducing external inputs and improving internal resources. Organic materials play key roles in terms of maintaining or improving soil fertility, soil organic matter and plant nutrition through the direct and indirect effects on microbial activity and nutrient availability (Clark et al. 1998).

The European Union Landfill Directive (Council of European Union, 1999) required the Member States to reduce the amount of biodegradable waste and improve activities, such as recovery and recycling. Food waste is large component of the waste stream by weight and constitutes in Hungary. Hotels, restaurants, food chains, food factories produce a lot of tons of organic waste that may be composted. If these wastes can be composted to obtain a quality organic soil amendment with humified organic matter and the end product used as soil organic amendment or fertilizer, this may represent one of the alternatives for achieving the goal of ensuring integrated and sustainable waste management (Chang \& Tin-En Hsu, 2008).

While programs and facilities to manage any waste are well established, the management of food waste in collecting for treatment in central composting facilities is perhaps only in its infancy (Levis et al. 2010). Use of food waste compost can be a good alternative for increasing crop production by enhancing soil productivity. Food waste compost is generally higher in nutrient value and lower in contamination than most other types of compost, thus making it more valuable in the market (Roberts et al, 2007).

Use of microbial preparations for enhancement of plant production is becoming a new practice in many countries (Rodriguez \& Fraga, 1999; Higa, 1994). Bacterial fertilizers may contain different microorganisms, for example nitrogen fixing and phosphates solubilizing microorganisms. They have the ability to fix nitrogen from the air and to solubilize phosphate minerals and so make nitrogen and phosphorus available to plants. Biofertilizers may increase the soil microbial sources, improve crop nutrition conditions, may accelerate the decomposition of organic wastes, increase the availability of mineral nutrients, can dissolve soil phosphorus, potassium, can increase the nitrogen content of soil and may enhance the activities of beneficial microorganisms.

Results of different studies with microbial inoculants have been highly variable. According to many researchers microbial inoculants are promising components of integrated 
nutrient management systems, other investigators have found less expressed effects of applied biofertilizer (Richardson, 2001; Wu et al., 2005; Hegedus et al., 2008; Schenk \& Müller, 2009; Kincses et al. 2008).

The objective of this study was to compare the effects of food waste compost, a commercially available bacterial fertilizer (EM-1) and their combined applications on biomass production and nutrient content of carrot with the effects of mineral fertilizer $\left(\mathrm{NH}_{4} \mathrm{NO}_{3}\right)$ and untreated pots.

\section{Materials and methods}

The greenhouse pot experiment was performed on carrot (Daucus carota, Katop F1) in a calcareous chernozem soil and in an acidic sandy soil. The soils are characterized by higher and lower organic matter contents, respectively. Some properties of soils used in trial are included in Table 1.

Table 1. Characteristics of the experimental soils

\begin{tabular}{|l|c|c|}
\hline & Calcareous chernozem soil & Sandy soil \\
\hline $\mathrm{pH}(\mathrm{KCl})$ & 6.5 & 4.5 \\
\hline $\mathrm{K}_{\mathrm{A}}$ & 42 & 26 \\
\hline $\mathrm{Hu} \%$ & 3.02 & 0.67 \\
\hline $\mathrm{AL}-\mathrm{P}_{2} \mathrm{O}_{5}\left(\mathrm{mg} \mathrm{kg}^{-1}\right)$ & 352.4 & 190.6 \\
\hline $\mathrm{AL}-\mathrm{K}_{2} \mathrm{O}\left(\mathrm{mg} \mathrm{kg}^{-1}\right)$ & 1254 & 217.2 \\
\hline
\end{tabular}

$\mathrm{K}_{\mathrm{A}}$ : Plasticity index according to Arany

Ten $\mathrm{kg}$ soil was weighed into Mitscherlich type pots. Different fertilization options (mineral and organic fertilization) and bacterial fertilizer were compared in a complete randomized design with four replicates and eight treatments: 1) unfertilized control; 2) nitrogen fertilizer, $\mathrm{NH}_{4} \mathrm{NO}_{3}$ (1000mg N pot ${ }^{-1}$, the dose of nitrogen was based on the nitrogen requirement of carrot)); 3) food waste compost at rate of $135 \mathrm{~g} / 10 \mathrm{~kg}$ soil; means $40 \mathrm{t} / \mathrm{ha}$; 4) half dose of food waste compost + half dose of mineral nitrogen. The 1, 2, 3, 4 treatments were complete with EM-1 bacterial fertilizer as 5, 6, 7 and 8 treatments. For the treatment applied see Table 2.

Table 2. Scheme of treatments applied

\begin{tabular}{|l|c|c|}
\hline \multirow{2}{*}{ Different $\mathrm{N}$ forms } & \multicolumn{2}{|c|}{ EM-1 Bacterial fertilizer } \\
\cline { 2 - 3 } & no & yes \\
\cline { 2 - 3 } & treatment code & treatment code \\
\hline control & 1. & 5. \\
\hline $\mathrm{NH}_{4} \mathrm{NO}_{3}$ & 2. & 6. \\
\hline Compost & 3. & 7. \\
\hline Compost $+\mathrm{NH}_{4} \mathrm{NO}_{3}$ & 4. & 8 \\
\hline
\end{tabular}

Compost was obtained from restaurant food residuals. Food residuals are mixed with wood waste and the blended materials are assembled into outdoor windrows and are composted for a total of 90 days. The main characteristics of food waste compost are described in Table 3.
Table 3. Characteristics of the food waste compost applied to the pots

\begin{tabular}{|l|l|}
\hline ash $\%$ & 19.12 \\
\hline dry matter\% & 97.7 \\
\hline $\mathrm{N} \%$ & 1.99 \\
\hline $\mathrm{C} \%$ & 31.5 \\
\hline $\mathrm{S} \%$ & 0.313 \\
\hline $\mathrm{C}: \mathrm{N}$ & 15.9 \\
\hline $\mathrm{pH}(1: 5)$ & 6.41 \\
\hline AL-P2O5 (mg kg-1) & 2736 \\
\hline AL-K2O (mg kg-1) & 673 \\
\hline
\end{tabular}

The applied bacterial fertilizer was a commercially distributed biofertilizer in Hungary, EM-1, which contains different species that belong to for example Azotobacter croococcum, Bacillus megatherium soil bacteria, microelements, heteroauxin, gibberelin, vitamin B. Before application, EM-1 was diluted one-hundredfold and $11 \mathrm{~cm}^{3}$ $10 \mathrm{~kg} \mathrm{soil}^{-1}$ (means 32 1/ha) was mixed into appropriate pots.

Ion exchanged water was added to all pots to keep the soil at constant moisture ( $60 \%$ of the water-holding capacity) using daily weighing.

Six seeds of carrot (Daucus carota) were sown at 11 April and the harvesting process was done at 22 July. Yield, weights of leaves and roots, diameter and length of roots were determined. Total carotenoid content of carrot roots was determined after acetate-hexane extraction by spectrophotometrically at $450 \mathrm{~nm}$ (MSZ 6830/14-84).

For elemental analysis, plant leaves and roots after drying at $50 \mathrm{C}^{\mathrm{O}}$ were digested by $\mathrm{H}_{2} \mathrm{SO}_{4}-\mathrm{H}_{2} \mathrm{O}_{2}$ method. Total phosphorus content of plant was determined by vanadatemolybdate method given by Olsen \& Sommers (1982). Potassium content of plant was analysed by atomic emission spectrophotometry. Nitrate was determined by ionchromatography (Kovács \& Loch, 2004). The total nitrogen and sulphur analysis was performed by dry combustion method (Nagy, 2000).

The experimental design was randomized complete block with four replications. Analysis of variance (one-way ANOVA) was carried out on the data in order to provide a statistical comparison between the treatment means. The least significant difference (LSD) test $(\mathrm{P}=0.05)$ was used to detect differences between means.

\section{Results and discussion}

\section{Growth response of carrot to soil-fertility treatments}

The plant biomass, the weights of roots and leaves, the length and diameter of carrot roots are presented in Table 4.

Mineral fertilizer in chernozem soil altered the weights of leaves, the less important parts of the crop without any effect on roots, the more important, edible part of carrot. The leave/root ratio also increased by the addition of $\mathrm{NH}_{4} \mathrm{NO}_{3}$. Food waste compost in chernozem soil did not 
Table 4. Effects of treatments on plant biomass and yield parameters

\begin{tabular}{|c|c|c|c|c|c|c|c|c|c|c|c|c|}
\hline \multirow[t]{2}{*}{ Treatment } & \multicolumn{2}{|c|}{$\begin{array}{l}\text { weight of roots } \\
\qquad\left(\mathrm{g} \mathrm{pot}^{-1}\right)\end{array}$} & \multicolumn{2}{|c|}{$\begin{array}{l}\text { weight of leaves } \\
\qquad\left(\mathrm{g} \mathrm{pot}^{-1}\right)\end{array}$} & \multicolumn{2}{|c|}{$\begin{array}{c}\text { ratio of weights of } \\
\text { leave/root }\end{array}$} & \multicolumn{2}{|c|}{$\begin{array}{c}\text { plant biomass } \\
\left(\mathrm{g} \mathrm{pot}^{-1}\right)\end{array}$} & \multicolumn{2}{|c|}{$\begin{array}{l}\text { length of roots } \\
(\mathrm{cm})\end{array}$} & \multicolumn{2}{|c|}{$\begin{array}{l}\text { diameter of roots } \\
(\mathrm{cm})\end{array}$} \\
\hline & chern. & sandy & chern. & sandy & chern. & sandy & chern. & sandy & chern. & sandy & chern. & sandy \\
\hline 1. control & $458 \mathrm{a}$ & $67.3 \mathrm{a}$ & $84.10 \mathrm{a}$ & $16.4 \mathrm{a}$ & $0.184 a$ & $0.244 \mathrm{a}$ & $542 \mathrm{a}$ & $83.7 \mathrm{a}$ & $14.0 \mathrm{a}$ & $9.1 \mathrm{a}$ & $3.14 \mathrm{a}$ & $1.67 \mathrm{a}$ \\
\hline 2. AN & $445 \mathrm{a}$ & $4.11 b$ & $116.2 b$ & $3.13 b$ & $0.261 b$ & $0.762 b$ & $562 \mathrm{a}$ & $7.24 b$ & $12.6 \mathrm{~b}$ & $3.5 b$ & $3.13 \mathrm{a}$ & $0.62 b$ \\
\hline 3. compost & $482 \mathrm{a}$ & $92.3 \mathrm{c}$ & $87.20 \mathrm{a}$ & $22.1 \mathrm{c}$ & $0.181 \mathrm{a}$ & $0.240 \mathrm{a}$ & $569 a$ & $114.4 \mathrm{c}$ & $15.3 \mathrm{c}$ & $9.9 \mathrm{a}$ & $3.20 \mathrm{a}$ & $1.88 \mathrm{c}$ \\
\hline 4. $\mathrm{AN}+$ compost & $496 \mathrm{a}$ & $52.4 \mathrm{~d}$ & $110.9 b$ & $16.2 \mathrm{a}$ & $0.225 \mathrm{c}$ & $0.309 \mathrm{a}$ & $607 b$ & $68.6 \mathrm{~d}$ & $14.5 \mathrm{a}$ & $9.2 \mathrm{a}$ & $3.48 b$ & $1.44 d$ \\
\hline 5. EM-1 & $462 \mathrm{a}$ & $65.8 \mathrm{a}$ & $86.40 \mathrm{a}$ & $16.8 \mathrm{a}$ & $0.187 \mathrm{a}$ & $0.255 \mathrm{a}$ & $549 \mathrm{a}$ & $82.7 \mathrm{a}$ & $14.3 \mathrm{a}$ & $9.6 \mathrm{a}$ & $3.13 \mathrm{a}$ & $1.62 \mathrm{a}$ \\
\hline 6. $\mathrm{AN}+\mathrm{EM}-1$ & $522 b$ & $7.42 b$ & $123.0 \mathrm{~b}$ & $2.83 b$ & $0.237 \mathrm{c}$ & $0.378 \mathrm{a}$ & $645 b$ & $10.2 b$ & $13.7 \mathrm{a}$ & $3.1 \mathrm{~b}$ & $3.48 b$ & $0.83 \mathrm{e}$ \\
\hline 7. comp.+EM-1 & $491 \mathrm{a}$ & $92.9 \mathrm{c}$ & $90.50 \mathrm{a}$ & $21.3 \mathrm{c}$ & $0.184 \mathrm{a}$ & $0.229 \mathrm{a}$ & $581 \mathrm{a}$ & $114.2 \mathrm{c}$ & $15.2 \mathrm{c}$ & $9.8 \mathrm{a}$ & $3.34 \mathrm{c}$ & $1.84 \mathrm{c}$ \\
\hline 8.AN+comp.+EM1 & $549 \mathrm{c}$ & $52.8 \mathrm{~d}$ & $114.1 b$ & $15.8 \mathrm{a}$ & $0.208 \mathrm{a}$ & $0.300 \mathrm{a}$ & $663 b c$ & $68.6 \mathrm{~d}$ & $15.7 \mathrm{c}$ & $7.8 \mathrm{c}$ & $3.49 b$ & $1.52 \mathrm{~d}$ \\
\hline Significance & $* *$ & $* * *$ & $* * *$ & $* * *$ & $* * *$ & $* * *$ & $* * *$ & $* * *$ & $* * *$ & $* * *$ & $* * *$ & $* * *$ \\
\hline
\end{tabular}

$* *$. $* * *=$ effect significant at $\mathrm{P}<0.01$ and $\mathrm{P}<0.001$, respectively. $\mathrm{AN}=$ ammonium-nitrate; $\mathrm{EM}-1=$ bacterial fertilizer

Means followed by the same letter are not significantly different (Tukey's studentized range test, $\mathrm{P}<0.05$ )

alter the plant biomass, but caused significantly longer roots. With combined treatment of ammonium-nitrate and compost an increasing trend appeared in root weights and the plant biomass and the diameter of roots also were the highest. Inoculation of chernozem soil with EM-1 did not resulted in changed plant biomass or yield parameters compared to control. Nevertheless when EM-1 bacterial fertilizer was applied in combination with ammoniumnitrate the plant biomass and the sizes of roots became higher compared to the values of appropriate treatments without inoculation. In chernozem soil the maximum weights and sizes of roots, the most favourable leave to root ratio were achieved with the combined treatment of $\mathrm{NH}_{4} \mathrm{NO}_{3}+$ food waste compost+EM-1.

In sandy soil a reduction in the plant biomass and sizes of roots appeared when ammonium-nitrate fertilization was applied. On this acidic sandy soil $\mathrm{NH}_{4} \mathrm{NO}_{3}$ might have been an intensely acidifying effect, causing the reduced increased of plant. A similar negative effect of $\mathrm{NH}_{4}$-salt mineral fertilizer on biomass production of maize in acidic sandy soil was reported by Kádár \& Pusztai (1997). Sánchez et al. (2000) also have experienced that application of high $\mathrm{NH}_{4} \mathrm{NO}_{3}$ rates in green bean resulted reduced biomass production.

As contrasted with the effect of $\mathrm{NH}_{4} \mathrm{NO}_{3}$, the addition of food waste compost to sandy soil had a beneficial effect on the plant biomass. The compost caused the greatest favourable changes in the plant biomass yield compared to other treatments. The highest plant biomass, the highest root and leaf weights, the most favourable leaf to root ratio was obtained with compost treatment. The combined treatment of compost and ammonium-nitrate in sandy soil, resulted in lower yield parameters as compared to sole compost treatment or control, but resulted in higher values compared to sole $\mathrm{NH}_{4} \mathrm{NO}_{3}$ treatment. Biofertilizer, EM-1 did not cause marked effect on the yield parameters of plant on sandy soil either with sole or combined applications.

\section{Nutrient content of carrot}

The total $\mathrm{N}, \mathrm{NO}_{3}-\mathrm{N}$, total $\mathrm{S}, \mathrm{SO}_{4}{ }^{2-}-\mathrm{S}, \mathrm{P}$ contents and $\mathrm{N} / \mathrm{S}$ ratios of plant and total carotenoid content of roots grown on two types of soils are presented in Table 5.

Higher $\mathrm{N}$ concentration was found in the leaves and lower in the edible portion of the crop. The $\mathrm{NO}_{3}-\mathrm{N}$ content was almost the same in both parts of plant. Hermann \& Bernier (1975) found, that in their experiment the total $\mathrm{N}$ concentration in carrot leaves and roots were quite similar, but nitrate concentration differed enormously, being much greater in the leaves.

The sulphur, sulphate and phosphorus mainly accumulated in the leaves than in the roots. Warman \& Havard (1997) reported values for the mineral composition of carrot root and leaves which are similar to the present data, with the exception of phosphorus content which was lower $(0.24 \%, 0.30 \%$, in the roots and leaves, respectively) in their results. The higher phosphorous values $(0.319-0.544 \%$, in the roots and leaves) obtained in the present study can probably attributed to the different fertility level of soils and the dissimilar availability of other nutrients.

The total carotenoid content of roots changed between 44.2-73.5 mg kg-1 , FW. The same carotenoid content (40-55 $\mathrm{mg}$ carotene $\mathrm{kg}^{-1}$, FW) of carrot root reported Evers (1989) and Hochmuth, et al., (1999) in their experiments.

Ammonium nitrate in chernozem soil increased the total $\mathrm{N}$ and $\mathrm{NO}_{3}-\mathrm{N}$ mostly in the leaves than in the roots suggesting the transport of nitrate ions from the root towards the leaves. Smolen \& Wlodzimierz (2009) also reported that in their experment they did not realised statistically significant effect on nitrate concentration in carrot storage roots by nitrogen fertilization. Application of ammoniumnitrate enhanced the total sulphur content of plant, mainly in the leaves. At the same time the $\mathrm{SO}_{4}{ }^{2}-\mathrm{S}$ of leaves and roots decreased compared to control. This means nitrogen had effect on the building of the sulphate into organic 
Table 5. Effects of treatments on nutrient and carotenoid contents of carrot

\begin{tabular}{|c|c|c|c|c|c|c|c|c|c|c|c|c|c|c|c|c|}
\hline \multirow{3}{*}{ Treatment } & \multicolumn{4}{|c|}{ N\% (DW) } & \multicolumn{4}{|c|}{$\mathrm{NO}_{3-} \mathrm{N} \%(\mathrm{DW})$} & \multicolumn{4}{|c|}{$\mathrm{S} \%$ (DW) } & \multicolumn{4}{|c|}{$\mathrm{SO}_{4}^{2-}-\mathrm{S} \%(\mathrm{DW})$} \\
\hline & \multicolumn{2}{|c|}{ roots } & \multicolumn{2}{|c|}{ leaves } & \multicolumn{2}{|c|}{ roots } & \multicolumn{2}{|c|}{ leaves } & \multicolumn{2}{|c|}{ roots } & \multicolumn{2}{|c|}{ leaves } & \multicolumn{2}{|c|}{ roots } & \multicolumn{2}{|c|}{ leaves } \\
\hline & chern. & sandy & chern. & sandy & chern. & sandy & chern. & sandy & chern. & sandy & chern. & sandy & chern. & sandy & chern. & sandy \\
\hline 1. control & $0.95 \mathrm{a}$ & $0.800 \mathrm{a}$ & $1.19 \mathrm{a}$ & $2.24 \mathrm{a}$ & $0.180 \mathrm{a}$ & $0.176 \mathrm{a}$ & $0.174 \mathrm{a}$ & $0.163 a$ & $0.131 \mathrm{a}$ & $0.256 \mathrm{a}$ & $0.273 \mathrm{a}$ & $0.826 \mathrm{a}$ & $0.086 \mathrm{a}$ & $0.056 \mathrm{a}$ & $0.345 \mathrm{a}$ & $0.701 \mathrm{a}$ \\
\hline 2. AN & $1.36 \mathrm{~b}$ & $2.47 \mathrm{~b}$ & $1.95 \mathrm{~b}$ & $3.84 b$ & $0.185 a$ & $0.332 \mathrm{~b}$ & $0.206 b$ & $0.192 \mathrm{~b}$ & $0.140 \mathrm{a}$ & $0.155 b$ & $0.324 b$ & $0.477 \mathrm{~b}$ & $0.072 b$ & $0.089 \mathrm{~b}$ & $0.097 \mathrm{~b}$ & $0.084 \mathrm{~b}$ \\
\hline 3. compost & $1.00 \mathrm{a}$ & $0.878 \mathrm{a}$ & $1.33 \mathrm{c}$ & $2.21 \mathrm{a}$ & $0.183 a$ & $0.178 \mathrm{a}$ & $0.184 \mathrm{a}$ & $0.179 \mathrm{a}$ & $0.134 \mathrm{a}$ & $0.182 b$ & $0.288 \mathrm{a}$ & $0.583 \mathrm{c}$ & $0.074 \mathrm{~b}$ & $0.057 \mathrm{a}$ & $0.318 \mathrm{c}$ & $0.478 \mathrm{c}$ \\
\hline 4. AN+ compost & $1.11 \mathrm{c}$ & $1.26 \mathrm{c}$ & $1.61 \mathrm{~d}$ & $2.81 \mathrm{c}$ & $0.185 a$ & $0.210 \mathrm{c}$ & $0.176 a$ & $0.327 \mathrm{c}$ & $0.142 \mathrm{a}$ & $0.191 b$ & $0.266 \mathrm{a}$ & $0.353 \mathrm{~d}$ & $0.084 \mathrm{a}$ & $0.076 \mathrm{~b}$ & $0.157 \mathrm{~d}$ & $0.226 \mathrm{~d}$ \\
\hline 5. EM-1 & $0.89 \mathrm{a}$ & $0.846 \mathrm{a}$ & $1.20 \mathrm{a}$ & $2.24 \mathrm{a}$ & $0.196 a$ & $0.181 \mathrm{a}$ & $0.184 \mathrm{a}$ & $0.179 a$ & $0.141 \mathrm{a}$ & $0.154 \mathrm{~b}$ & $0.296 \mathrm{a}$ & $0.802 \mathrm{a}$ & $0.078 \mathrm{a}$ & $0.071 \mathrm{~b}$ & $0.471 \mathrm{e}$ & $0.691 \mathrm{a}$ \\
\hline 6. AN+EM-1 & $1.28 \mathrm{~b}$ & $2.86 \mathrm{~d}$ & $2.04 \mathrm{~b}$ & $4.09 b$ & $0.172 \mathrm{a}$ & $0.310 \mathrm{~d}$ & $0.202 b$ & $0.167 \mathrm{a}$ & $0.130 \mathrm{a}$ & $0.160 \mathrm{~b}$ & $0.306 \mathrm{a}$ & $0.468 b$ & $0.081 \mathrm{a}$ & $0.113 \mathrm{c}$ & $0.156 \mathrm{~d}$ & $0.173 \mathrm{e}$ \\
\hline 7. comp.+EM-1 & $1.17 \mathrm{c}$ & $0.927 \mathrm{a}$ & $1.33 \mathrm{c}$ & $2.22 \mathrm{a}$ & $0.187 \mathrm{a}$ & $0.180 \mathrm{a}$ & $0.187 \mathrm{a}$ & $0.198 b$ & $0.139 \mathrm{a}$ & $0.164 b$ & $0.308 \mathrm{a}$ & $0.742 \mathrm{a}$ & $0.081 \mathrm{a}$ & $0.080 \mathrm{~b}$ & $0.343 a$ & $0.677 \mathrm{a}$ \\
\hline $\begin{array}{l}\text { 8. AN+comp. } \\
\text { +EM }\end{array}$ & $1.16 \mathrm{c}$ & $1.25 \mathrm{c}$ & $1.58 \mathrm{~d}$ & $3.02 \mathrm{c}$ & $0.176 \mathrm{a}$ & $0.217 \mathrm{c}$ & $0.206 b$ & $0.329 \mathrm{c}$ & $0.130 \mathrm{a}$ & $0.161 \mathrm{~b}$ & $0.307 \mathrm{a}$ & $0.490 \mathrm{~b}$ & $0.094 \mathrm{a}$ & $0.075 b$ & $0.172 \mathrm{~d}$ & $0.246 \mathrm{~d}$ \\
\hline Significance & $* * *$ & $* * *$ & $* * *$ & $* * *$ & n.s. & $* * *$ & $* *$ & $* * *$ & n. s. & $*$ & $*$ & $* * *$ & $* * *$ & $* * *$ & $* * *$ & $* * *$ \\
\hline \multirow{3}{*}{ Treatment } & \multicolumn{4}{|c|}{$\mathrm{N} / \mathrm{S}$ ratio } & \multicolumn{4}{|c|}{$\mathrm{P} \%(\mathrm{DW})$} & \multirow{2}{*}{\multicolumn{8}{|c|}{ total carotenoid content of roots, $\mathrm{mg} \mathrm{kg}-1$ (FW) }} \\
\hline & \multicolumn{2}{|c|}{ roots } & \multicolumn{2}{|c|}{ leaves } & \multicolumn{2}{|c|}{ roots } & \multicolumn{2}{|c|}{ leaves } & & & & & & & & \\
\hline & chern. & sandy & chern. & sandy & chern. & sandy & chern. & sandy & \multicolumn{4}{|c|}{ chern. } & \multicolumn{4}{|c|}{ sandy } \\
\hline 1. control & $7.27 \mathrm{a}$ & $3.88 \mathrm{a}$ & $4.58 \mathrm{a}$ & $2.72 \mathrm{a}$ & $0.356 \mathrm{a}$ & $0.353 a$ & $0.426 \mathrm{a}$ & $0.319 \mathrm{a}$ & \multicolumn{4}{|c|}{$51.7 \mathrm{a}$} & \multicolumn{4}{|c|}{$44.7 \mathrm{a}$} \\
\hline 2. AN & $9.76 \mathrm{~b}$ & $15.9 \mathrm{~b}$ & $6.07 \mathrm{~b}$ & $8.48 \mathrm{~b}$ & $0.544 \mathrm{~b}$ & $0.391 b$ & $0.403 \mathrm{~b}$ & $0.361 \mathrm{~b}$ & \multicolumn{4}{|c|}{$64.2 \mathrm{a}$} & \multicolumn{4}{|c|}{$47.1 \mathrm{a}$} \\
\hline 3. compost & $7.46 \mathrm{a}$ & $5.02 \mathrm{a}$ & $4.63 \mathrm{a}$ & $3.80 \mathrm{a}$ & $0.398 \mathrm{a}$ & $0.398 b$ & $0.444 \mathrm{a}$ & $0.433 \mathrm{c}$ & \multicolumn{4}{|c|}{$73.2 \mathrm{~b}$} & \multicolumn{4}{|c|}{$60.7 b$} \\
\hline 4. AN+ compost & 7.32a & $6.71 \mathrm{c}$ & $6.08 \mathrm{~b}$ & $8.08 \mathrm{~b}$ & $\begin{array}{l}0.382 \\
\mathrm{ac}\end{array}$ & $0.382 b$ & $0.401 \mathrm{~b}$ & $0.370 \mathrm{~b}$ & & & $9 \mathrm{~b}$ & & & & $8 \mathrm{a}$ & \\
\hline 5. EM-1 & $5.91 \mathrm{c}$ & $5.54 \mathrm{a}$ & $4.22 \mathrm{a}$ & $2.79 \mathrm{a}$ & $0.365 \mathrm{a}$ & $0.365 \mathrm{a}$ & $0.472 \mathrm{c}$ & $0.360 \mathrm{~b}$ & & & $.1 \mathrm{a}$ & & & & $2 \mathrm{a}$ & \\
\hline 6. AN+EM-1 & $9.87 \mathrm{~b}$ & $18.1 \mathrm{~b}$ & $7.14 \mathrm{c}$ & $8.92 \mathrm{~b}$ & $0.466 \mathrm{c}$ & $0.466 c$ & $0.375 \mathrm{~d}$ & $0.411 c$ & & & $.1 \mathrm{a}$ & & & & $8 \mathrm{a}$ & \\
\hline 7. comp.+EM-1 & $8.38 \mathrm{~d}$ & $5.65 \mathrm{a}$ & $4.31 \mathrm{a}$ & $2.99 a$ & $0.408 \mathrm{a}$ & $0.387 \mathrm{~b}$ & $0.443 \mathrm{a}$ & $\begin{array}{l}0.402 \\
\mathrm{~cd}\end{array}$ & & & $.5 b$ & & & & $.3 b$ & \\
\hline $\begin{array}{l}\text { 8.AN+comp.+ } \\
\text { EM }\end{array}$ & $8.94 b$ & $7.73 c$ & $5.15 \mathrm{~d}$ & $6.56 \mathrm{~b}$ & $0.433 \mathrm{c}$ & $0.441 c$ & $\begin{array}{l}0.391 \\
\text { bd }\end{array}$ & $\begin{array}{l}0.390 \\
\text { cd }\end{array}$ & & & $8 \mathrm{a}$ & & & & $8 \mathrm{~b}$ & \\
\hline Significance & $* * *$ & $* * *$ & $* * *$ & $* * *$ & $* * *$ & $* * *$ & $* * *$ & $* * *$ & & & $*$ & & & & $* *$ & \\
\hline
\end{tabular}

$+, *, * * * * *=$ effect significant at $\mathrm{P}<0.1, \mathrm{P}<0.05, \mathrm{P}<0.01$ and $\mathrm{P}<0.001$, respectively, n.s. $=$ not significant, $\mathrm{AN}=$ ammonium-nitrate; EM-1=bacterial fertilizer

Means followed by the same letter are not significantly different (Tukey's studentized range test, $\mathrm{p}<0.05$ ).

compounds. Ammonium-nitrate resulted in increased phosphorus content of roots, while probably due to a dilution effect, decreased $\mathrm{P}$ of leaves.

In sandy soil the total $\mathrm{N}$ and especially $\mathrm{NO}_{3}-\mathrm{N}$ content of carrot roots highly increased $\left(\mathrm{NO}_{3}-\mathrm{N}: 0.332 \%\right.$ (DW) means $\mathrm{NO}_{3}^{-}: 2203 \mathrm{mg} \mathrm{kg}^{-1}(\mathrm{FW})$ by water content of $75 \%$ ) due to the application of ammonium-nitrate. Nitrate exceed the limit according to EC Regulation (for carrot: $1500 \mathrm{mg} \mathrm{kg}^{-1}$ FW, Santamaria, 2006) and was much higher than the maximum permitted level for nitrate in baby foods $(200 \mathrm{mg}$ $\left.\mathrm{kg}^{-1} \mathrm{FW}\right)$ permitted by the European Commission (EC, 2004). In this treatment the sharp fall in root and leaf biomass also appeared. High concentration of nitrate in carrot might have resulted from a worse utilization of nitrogen by plant. Andreeva et al. (1998) also found that increased $\mathrm{NO}_{3}{ }^{-}$content above the optimum substantially suppressed apparent and potential photosynthesis and reduced plant productivity. In this treatment the total sulphur content of roots and leaves also decreased, that is why the $\mathrm{N}$ to $\mathrm{S}$ ratios of root highly increased (15.9) compared to control (3.88) and other treatments. The same high change in $\mathrm{N} / \mathrm{S}$ ratio of carrot (from 23 to 10) with greatly differing rates of N, P, K, Ca and $\mathrm{S}$ was reported by Eppendorfer \& Eggum (2005). Ammonium-nitrate resulted in poorer transport of sulphate and nitrate from the root towards the leaves and minor building up these ions into organic compounds. In mineral fertilizer treatment the phosphorus content of both part of plant were higher compared to control because of lower yield.

Food waste compost in chernozem soil enhanced the nitrogen content of leaves, but did not cause remarkable change in the $\mathrm{NO}_{3}-\mathrm{N}, \mathrm{P}$ and $\mathrm{S}$ contents. In sandy soil compost caused increased $\mathrm{P}$ content of roots and leaves. Compost mineralized during the growing season and supply phosphorus to plant. At the same time the total $\mathrm{S}_{\text {and }} \mathrm{SO}_{4}{ }^{2}-\mathrm{S}$ content of plant decreased due to dilution effect (Jarrell \& Beverly, 1981).

Higher carotenoid content in both soil types were obtained in compost treatment compared to other treatments.

Combined application of half dose of food waste compost 
and nitrogen fertilizer in chernozem soil caused an increased total $\mathrm{N}$ of plant compared to control, but the $\mathrm{NO}_{3}-\mathrm{N}$ of carrot did not changed. In this treatment the phosphorus content of leaves decreased.

In sandy soil application of combined treatment of mineral fertilizer+compost resulted in higher total $\mathrm{N}, \mathrm{NO}_{3}-\mathrm{N}$ and phosphorus content of plant compared to control. The $\mathrm{NO}_{3}-\mathrm{N}$ of leaves increased more than roots values. The $\mathrm{NO}_{3}-\mathrm{N}$ of roots was not higher than the limits to maximum levels of nitrate of carrot accepted in European countries (Santamaria, 2006). In this combined treatment while the $\mathrm{N}$ content of plant enhanced, the sulphur content decreased and as a result of this the N/S ratio increased in both parts of the plant.

Sole application of EM-1 bacterial fertilizer enhanced the $\mathrm{P}$ content of leaves compared to control. The increasing effect was significant in both soil types. Bacterial fertilizer contains phosphates solubilising bacteria which might solubilise phosphate minerals in soils and make phosphorus more available for carrot. Vassilev et al. (2006) have shown in their experiments an increased $\mathrm{P}$ uptake by plants through the inoculation of phosphates solubilising microorganisms.

When EM-1 bacterial fertilizer was applied in combination with compost an enhancement of roots nitrogen appeared, compared to values of sole compost treatment. The effect appeared in both soil type but was significant in chernozem soil. EM-1 bacterial fertilizer contains Azotobacter croococcum soil bacteria with ability to fix the nitrogen from the air. In order to do that, these bacteria need optimal soil conditions. Food waste compost supplied nutrients for bacteria, created favourable conditions for their multiplication. In this combined treatment the $\mathrm{SO}_{4}{ }^{2-} \mathrm{S}$ content of roots and leaves also were higher compared the value of compost treatment.

With combined application of ammonium-nitrate+EM-1 or $\mathrm{NH}_{4} \mathrm{NO}_{3}+$ compost+EM-1 in sandy soil the phosphorus content of plant increased compared to appropriate treatment being not inoculated.

Although the compost treatment increased the carotenoid content of roots, either inoculation of soils or nitrogen fertilizer application did not result any significant change of these values. The same was also observed in the study of Leclerc et al., (1991) who found that in paired comparison of conventional and organic method, organic fertilization produced higher carotenoid content in carrots. As opposed to this, in a comparison of mineral fertilizer and compost Salomon (1972) found that carrot fertilized with compost or mineral fertilizer did not differ in the levels of carotene. Gajewski et al., (2010) also concluded that nitrogen fertilizer did not significantly influence carotenoid content in the roots. Their results showed that carotenoid accumulation in the roots was significantly affected by carrot genotype.

\section{Conclusion}

The same dose of $\mathrm{NH}_{4} \mathrm{NO}_{3}$ caused different effects on biomass production in two different soil types. In acidic sandy soil, where the buffer systems: soil colloids, humic substances, clay minerals are limited, $\mathrm{NH}_{4} \mathrm{NO}_{3}$ had an intensely acidifying effect and resulted in reduced increased of carrot plant and highly increased in $\mathrm{NO}_{3}-\mathrm{N}$ content of carrot roots. $\mathrm{NH}_{4} \mathrm{NO}_{3}$ had significant decreasing effect of the total sulphur content of roots and caused highly increased (15.9) N/S ratio of roots compared to control (3.88). In chernozem soil the effect of $\mathrm{NH}_{4} \mathrm{NO}_{3}$ on the plant biomass and yield of roots were not observed significantly. Nitrogen fertilizer increased the total nitrogen and phosphorus content of roots, the total carotenoid and sulphur content did not change. The N/S ratio slightly increased from 7.27 to 9.76.

Sandy soil showed higher response of biomass production and nutrients change in plant to food waste compost fertilization than chernozem soil. Food waste compost caused the highest total carotenoid content on both soil types. Compost increased the phosphorus of roots in sandy soil. Labrecque \& Teodorescu (2001) also recorded higher response of organic fertilization on growth of two willow species in sandy (poor) soil than in clay (good) soil.

The combination of half dose of compost and $\mathrm{NH}_{4} \mathrm{NO}_{3}$ in chernozem soil proved to be advantageous treatment, higher plant biomass, sizes of roots and higher $\mathrm{N}$ and $\mathrm{S}$ contents of carrot compared to values of control were recorded. In sandy soil the $\mathrm{NH}_{4} \mathrm{NO}_{3}+$ compost combined treatment proved to be less favourable than compost treatment, but was preferable as mineral fertilizer treatment.

Sole application of bacterial fertilizer did not influence the yield of carrot, but enhanced the phosphorus content of carrot leaves. With combined applications of $\mathrm{NH}_{4} \mathrm{NO}_{3}+\mathrm{EM}-$ 1 or $\mathrm{NH}_{4} \mathrm{NO}_{3}+$ compost+EM- 1 the $\mathrm{P}$ content of plant also increased compared to appropriate treatment being not inoculated. The effect was significant mainly in sandy soil.

In chernozem soil the maximum yield and yield parameters were achieved with the combined treatment of $\mathrm{NH}_{4} \mathrm{NO}_{3}+$ compost+EM-1 and in sandy soil with compost and compost+EM-1 treatments.

From the above studies, it is clear that effectiveness of food waste compost emerged as a promising management practice especially in soils having low organic material and low nutrient supply. Also it would be interesting to assess the nutrient residual effect of food waste compost application. EM-1 bacterial fertilizer did not cause marked effect on yield and yield parameters of carrot plant so further studies are needed.

\section{References}

Andreeva, T. F., Maevskaya, S. N., Voevudskaya, S. Y. (1998): The relationship between photosysnthesis and nitrogen assimilation in Mustard plants exposed to elevated nitrate rates in nutrient solutions. Russian Journal of Plant Physiology, 45: 702-705.

Kovács, B. A. \& Loch, J. (2004): Néhány anion ionkromatográfiás meghatározása talaj- és növénymintákban, Agrokémia és Talajtan. 53. (3-4): 391-400.

Chang J. I. \& Tin-En Hsu, (2008): Effects of compositions on food waste composting Bioresource Technology. 99. (17): 256-278. 
Clark, M. S., Horwath, W. R., Shennan, C., Scow, K. M. (1998): Changes in soil chemical properties resulting from organic and lowinput farming practices. Agronomy Journal, 90: 662-671.

Council of the European Union (1999): Directive 1999/31/EC, of 26 April 1999, On the landfill of waste.

EC (European Commission), Commission Regulation (EC) (2004): No. 655/2004 of 7 April 2004 amending Regulation (EC) No 466/2001 as regards nitrate in foods for infants and young children. Official Journal of Europian Communities, L104: 48-49.

Eppendorfer, W. H. \& Eggum, B. O. (2005): Effects of Nitrogen, Phosphorus, Sulphur, Potassium, alcium and Water Stress on Yield, Mineral and Amino Acid Composition, Dietary Fibre and Nutritive Value of Carrots. Acta Agriculturae Scandinavica. 45, (2): 124-131.

Evers, A. M., (1989): Effects of dfferent fertilization practices on the carotene content of carrot. Journal of Agricultural Science in Finland, 61: 7-14.

Gajewski, M., Weglarz, Z., Sereda, A., Bajer, M., Kuczkowska, A., Majewski, M. (2010): Carotenoid accumulation ba carrot storage roots in realtion to nitrogen fertilization level. Notule Botanicae Horti Agrobotanici Cluj-Napoca, 38: 71-75.

Hegedus, S., Kristo, I., Litkei, Cs., Vojnich, V., (2008): Impact of bacterial fertilizer on the component of industrial poppy varieties. Cereal Research Communication. 36. Part 3 Suppl., 1719-1722.

Hermann, H. A. \& Bernier, R. (1975): N-P-K fertilizer effects on yield, composition and residues of lettuce, celery, carrot and onion grown on an organic soil in Quebec. Canadian Journal of Plant Science, 55: 453-461.

Higa, T. (1994): Effective Microorganisms; A biotechnology for mankind, P 8-14. In J.F. Parr, S.B. Hornick and C.E. Whitman(ed.) Proceedings of the First International Conference on Kyusei Nature Farming. U.S Department of Agriculture, Washington, D.C., USA

Hochmuth, G. J., Brecht, J. K., Basseth, M. J. (1999): Nitrogen fertilization to maximize carrot yield and quality on a sandy soil. Hortscience. 34. (4): 641-645.

Jarrell, W. M., \& Beverly, R. B. (1981): The dilution effect in plant nutrition studies. Advances in Agronomy, 34: 197-224.

Kádár, I. \& Pusztai, A. (1997): N-műtrágyák hatásának vizsgálata tenyészedény-kísérletekben III. Savanyú homoktalaj (Nyírlugos) Agrokémia és Talajtan, 46. 1-4. 245-256.

Kincses I., Filep T., Kremper R., Sipos M. (2008): Effect of nitrogen fertilization and biofetilization on element content of parsley Cereal Research Communication Volume, 36. 1: 571-574.

Labrecque, M. \& Teodorescu, T. I. (2001): Influnece of plantation site and wastewater sludge fertilization on the performance and foliar nutrient status of two willow species grown under SRIC in southern Quebec (Canada). Forest Ecology and Management. 150: 223-239.

Leclerc, J., Miller, M. L., Jliet, E., Rocquelin, G., (1991): Vitamin and mineral contents of carrot and celeriac grown under mineral or organic fertilization. Biological Agriculture \& Horticulture, 7: 339-348.
Levis, J. W., Barlaz, M. A., Themelis, N. J., Ulloa, P. (2010): Assessment of the state of food waste treatment in the United States and Canada Waste Management, 30. (8-9): 1486-1494.

MSZ 6830/14-84: Takarmányok táplálóértékének megállapítása, Karotin- és xantofilltartalom meghatározása.

Nagy, P.T. (2000): Égetéses elven működő elemanalizátor alkalmazhatósága talaj- és növényvizsgálatokban. Agrokémia és Talajtan., 49. (3-4): 521-534.

Olsen, S. R. \& Sommers, L. R. (1982): Phosphorus. [In: Agronomy Series 9, eds. A. L. Page, R. H. Miller and D. R. Kenny], p. 403. Madison, WI: American Society Agronomy.

Petróczki, F. (2004): Effect of sewage sludge and slaughterhouse waste compost on plant growth. Acta Agronomica Hungarica, 52. (3): 253-261.

Richardson, A. E., (2001): Prospects for using soil microorganisms to improve the acquisition of phosphorus by plants. Australian Journal of Plant Physiology, 28. (9): 897-906.

Roberts, P., Edwards, G., Jones, P. G., Jones, D.L. (2007): Invessel cocomposting of green waste with biosolids and paper waste, Compost Science and Utilization, 15: 272-282.

Rodriguez, H. \& Fraga, R. (1999): Phosphate solubilizing bacteria and their role in plant growth promotion, Biotechnology Advences, 17: 319-339.

Sánchez, E., Soto, J. M., Garcia, P. C., López-Lefebre, L. R., Rivero, R. M., Ruiz, J. M., Romero, L., (2000): Phenolic compounds and oxidative metabolism in green bean plants under nitrogen toxicity. Australian Journal of Plant Physiology, 27: 272-277.

Santamaria, P. (2006): Review Nitrate in vegetables: toxicity, content, intake and EC regulation, Journal of the Science of Food and Agriculture, 86: 10-17.

Salomon, M. (1972): Natural foods-myth or magic. Assoc. Food Drug Off. US Q. Bulletin, 36: 131-137.

Schenk, M. zu Schweinsberg-Mickan \& Müller, T., (2009): Impact of effective microorganisms and other biofertilizers on soil microbial characteristics, organic-matter decomposition, and plant growth. Journal of Plant Nutrition of Soil Science, 172: 704-712.

Smolen, S. \& Wlodzimierz, S. (2009): The effect of various nitrogen fertilization and foliar nutrition regimes on the concetntrations of nitrates, ammonium ions, dry matter and N-total in carrot (Daucus carota L.) roots. Scientia Horticulturae, 119: 219-231.

Vassilev, N., Medina, A., Azcon, R., Vassileva, M. (2006): Microbial solubilization of rock phosphate on media containing agro- industrial wastes and effect of the resulting product on plant growth and P-uptake. Plant Soil., 287: 77-84.

Warman, P. R. \& Havard, K. A. (1997): Yield, vitamin and mineral contents of organically and conventionally grown carrots and cabbage. Agriculture, Ecosystems and Environment, 61: $155-162$.

Wu, S.C., Cao, Z.H., Li Z.G., Cheung, K.C., Wong, M.H., (2005): Effects of biofertilizer containing $\mathrm{N}$-fixer, $\mathrm{P}$ and $\mathrm{K}$ solubilizers and AM fungi on maize growth: a greenhouse trial, Geoderma, 125: 155-166. 